\title{
Plemenito dejanje brnskih etimologov
}

\author{
Metka Furlan
}

Cobiss: 1.19

Sebrané spisy Václava Machka 1-2, ur. Ilona Janyšková - Helena Karlíková - Eva Havlová † - Radoslav Večerka: Praha, Nakladatelství Lidové noviny, 2011, 2296 str.

Václav Machek, Korespondence I-II, ur. Vít Boček - Petr Malčík, Praha: Nakladatelství Lidové noviny, 2011 (Studia etymologica Brunensia 12), 1031 str.

1 Med slovanskimi etimološkimi centri ima brnski, ki kot samostojna etimološka sekcija (Etymologické oddělení) deluje v okviru inštituta za češki jezik (Ústav pro jazyk český) pri češki akademiji znanosti (Akademie věd České republiky) danes vidnejše mesto, ker je nedvomno tudi zaradi lepega števila raziskovalcev različnih generacij vsestransko uspešen. Od leta 1989 dalje namreč redno izdaja etimološki slovar stare cerkvene slovanščine (Etymologický slovnik jazyka staroslověnského), ki danes obsega 16 zvezkov in je do leta 2012 prispel do obravnave besede trbtb 'rep', od leta 1999 pa redno organizira mednarodne znanstvene etimološke konference, katere zborniki se objavljajo v prav zato leta 2000 ustanovljeni knjižni zbirki Studia etymologica Brunensia, ki je do danes svoje poslanstvo razširila in objavlja tudi druge monografije s področja slovanske etimologije, tako da je do leta $2014 \mathrm{v}$ okviru nje izšlo že 17 knjižnih naslovov.

Zametki sodobne brnske etimološke delavnice segajo v leto 1952, ko je etimološko sekcijo tedaj še kot del slovanskega inštituta (Slovanský ústav) ustanovil profesor brnske univerze, svetovno znani indoevropeist in etimolog Václav Machek. Z objavo dveh obsežnih publikacij na skupno 3327 straneh, njegovih zbranih spisov (Sebrané spisy Václava Machka 1-2) in korespondence (Korespondence I-II), tik pred 60. obletnico ustanovitve njihove etimološke sekcije so brnski kolegi počastili spomin na svojega ustanovitelja in utemeljitelja sodobne češke etimologije ter poskrbeli, da njegov obsežni opus razprav in člankov zaradi časovne oddaljenosti ter razpršenosti po različnem domačem in tujem strokovnem revijalnem tisku ne bo potonil v pozabo. $\mathrm{V}$ času, ko se v znanosti tudi zaradi čedalje večjih pritiskov glede formalne uspešnosti, ki se praviloma meri po individualnih objavah, skupinsko delo vse bolj umika individualnemu, je dejanje brnskih kolegov, ki znajo stopiti skupaj, ko je to zaradi višjega cilja potrebno, toliko bolj plemenito, občudovanja in posnemanja vredno. 
Sama spadam v generacijo, ki etimologa in indoevropeista Václava Machka pozna le posredno, prek njegovih del, imela pa sem še srečo, da sem spoštljive besede o njem, njegovem znanstvenem opusu in etimološki metodi slišala od našega etimologa in onomasta Franceta Bezlaja, ki ga je kot 16 let mlajši globoko cenil in spoštovanje do njega prenesel tudi na mlajšo generacijo.

Václav Machek se je rodil 8. novembra $1894^{1}$ v vzhodnočeški vasici Brdek. Po maturi se je leta 1914 vpisal na praško filozofsko fakulteto, kjer je študiral češčino in latinščino. Zaradi izbruha prve svetovne vojne je diplomiral lahko šele spomladi leta 1921 in jeseni istega leta doktoriral. V slovansko primerjalno jezikoslovje sta ga vpeljala priznana profesorja Josef Zubatý in Oldřich Hujer. Kot štipendist francoske vlade se je strokovno izpopolnjeval pri slavnih Antoinu Meilletu, Josephu Vendryesu, Josephu Blochu in drugih. Po vrnitvi v domovino je bil v letih 1924-1936 gimnazijski profesor, v študijskem letu 1930/31 pa je bil pritegnjen k sodelovanju pri pripravi Slovníka jazyka českého v Pragi. Z delom Studie a tvoření výrazů expresivnich, ki je izšlo leta 1930, se je na brnski Masarykovi univerzi habilitiral leta 1931, leta 1936 pa je postal profesor za indoevropsko primerjalno jezikoslovje. Leta 1956 mu je bila podeljena čast doktorja filoloških znanosti, leta 1958 pa je postal vodja novoustanovljene katedre za slavistiko in primerjalno jezikoslovje. Impresivna je njegova široka tematika predavanj, ko je med letoma 1931 in 1965 na brnski univerzi poučeval indoevropsko in slovansko primerjalno jezikoslovje, ob katerih je poleg slovanskih jezikov predaval tudi litovščino, letščino, staro pruščino, staro indijščino, avestijščino, pali in toharščino. Pogosto je bila tema njegovih predavanj tudi domovina in kultura starih Indoevropejcev. Svojo življenjsko pot je Václav Machek sklenil 26. maja 1965 v Brnu.

Etimološka delavnica je bila leta 1952 v Brnu ustanovljena, ker se je v njej načrtovala izdelava etimološkega slovarja slovanskih jezikov, ${ }^{2}$ a je usoda kljub dobro načrtovanim pripravljalnim delom hotela, da sta pod naslovom Etymologický slovník slovanských jazyků že po Machovi smrti izšla le dva tematska zvezka s skupnim podnaslovom Slova gramatická a zájmena (1: predložky, koncové partikule, 1973; 2: spojky, částice, zájmena a zájmenná adverbia, 1980), del že izdelanih gesel za slovar pa je v letih 1990-1997 v več člankih izhajal v reviji Slavia pod naslovom Z materiálů Etymologického slovniku slovanských jayzků. ${ }^{3}$ Praslovanska etimološka slovarja se od leta 1974 dalje izdelujeta v dveh drugih etimoloških centrih, v moskovskem Ėtimologičeskij slovar' slavjanskih jazykov 1-38- (Moskva, 1974-2012-) in v krakovskem Słownik prasłowiański 1-8- (Kraków, 1974-2001-), brnski pa bogato gradivo, ki je bilo ekscerpirano za načrtovani etimološki slovar slovanskih jezikov, uporablja pri izdelavi dela Etymologický slovník jazyka staroslověnského.

1 Stoti obletnici rojstva Václava Machka je bila posvečena četrta številka 63. letnika revije

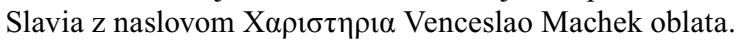

2 Leta 1966 je v Brnu pod uredništvom Eve Havlove izšel celo poskusni zvezek slovarja Etymologický slovník slovanských jazyků: ukázkové čislo (125 str.). Ob urednici so bili avtorji gesel še V. Čapková, F. Kopečný, A. Mátl in H. Plevačová.

3 Prispevki so v praški reviji Slavia izšli v tehle intervalih: 59 (1990), št. 3, 271-277; 60 (1991), št. 3, 316-320; 63 (1994), 149-157; 66 (1997), št. 1, 71-79; 66 (1997), št. 2, 179182; 66 (1997), št. 4, 447-454. 
Svojo prvo znanstveno publikacijo je Václav Machek objavil leta 1922, nekatera njegova dela pa so bila objavljena tudi še postumno. Njegov publicistični opus danes obsega 428 enot, med njimi je pet monografskih del. Ob Studie a tvoření výrazů expresivnich (1930), Recherches dans le domaine du lexique balto-slave (1934) in Česká a slovenská jména rostlin (1954) izstopata predvsem njegova etimološka slovarja. Leta 1957 je izdal Etymologický slovník jazyka českého a slovenského (1957), pripravljal pa je tudi že drugo, popravljeno in dopolnjeno izdajo s samo češkimi geselskimi iztočnicami, a ga je prehitela smrt, tako da je slovar z naslovom Etymologický slovník jazyka českého izšel postumno leta 1968, končno usklajevalno redakcijo zanj pa sta opravila Eva Havlová in Antonin Mátl. Do danes je bila ta izdaja etimološkega slovarja ponatisnjena že trikrat, v letih 1971, 1997 in 2010.

Václav Machek je bil predstavnik generacije slovanskih etimologov prve polovice prejšnjega stoletja, v kateri so izstopali tudi Max Julius Friedrich Vasmer (1886-1962), Petar Skok (1881-1956) in Stefan Mladenov (1888-1963) ne le zato, ker je vsakdo od njih slovanski nacionalni jezik oskrbel s svojim etimološkim slovarjem, ampak tudi, ker so kot jezikoslovni eruditi pomembno prispevali h kvalitativni in kvantitativni rasti in uveljavljanju slovanske etimologije. Václav Machek je v svoji generaciji izstopal tudi zato, ker ni ostajal v zavetju slovanskega jezikovnega in jezikoslovnega sveta, ampak je kot indoevropeist korenine slovanskega leksikalnega fonda iskal tudi s širše indoevropske perspektive. Naj izpostavim njegove prispevke na temo slovansko-baltskih, slovansko-germanskih, slovansko-latinskih, slovansko-grških, slovansko-keltskih in slovansko-hetitskih leksikalnih vezi (za slednje npr. het. and(a)ra- 'moder' : psl. *modrb 'isto'). Že s svojo monografijo iz leta 1930 je Machek pokazal posebno zanimanje za jezikovne pojave s področja ekspresivnega izražanja (npr. č. nevtralno spí 'spi' : ekspresivno ljubkovalno spinká 'spančka'). Afiniteta do prepoznavanja ekspresivno določenih fonetičnih pojavov (npr. mehčanje, dodajanje vzglasnih $\check{c}-, \check{s}-, \check{z}-, h$ namesto $k$, nazalizacija ...) tam, kjer načelo o brezizjemnosti glasoslovnih zakonov odpove, je močno izražena tudi v zadnjem njegovem monografskem delu, v etimološkem slovarju. V geslu lokati 'piti, požirati' zato združuje ekspresivno določene »fonetično neregularne « češke realizacije lohnit (> lonit), logat', lochat, pa tudi slovaške, npr. lokat', lohat', logat', lôchat'. Področje slovanskih ekspresivnih tvorb je bilo namreč do Machkovega nastopa razmeroma slabo raziskano. Ob pozornosti, ki jo je posvečal pojavom ekspresivnosti $\mathrm{v}$ jeziku, se je verjetno zavedel, da je v primerih, ko besedo z regularnim fonetičnim razvojem začnejo fonemsko preusmerjati »neregularni«, treba pri povezovanju medsebojno sorodnih besed semantiko (npr. 'piti, požirati') upoštevati bolj kot pa fonetiko (npr. lokati). Sicer pa je bil Machek zagovornik gibanja besed in stvari (Wörter und Sachen), ki je izpostavljalo, da je predzgodovina besed tesno povezana s predzgodovino realij = stvari in je zato $\mathrm{v}$ ospredje postavilo do tedaj zapostavljen študij razvoja besednega pomena. Lep primer take obravnave predstavlja že njegova študija iz leta 1924, v kateri je jezikovni ostanek gozdne čebelarske tehnike zapiranja naravnih drevesnih panjev z deskami prek č. dluž 'deska na sprednjem delu panja' in sorodnih slovanskih besed prepoznal v psl. samostalniku *dôlžb f 'deska, ki pokriva zarezo v naravnem drevesnem panju'. Vidni odraz globoke prepričanosti pomena gibanja Wörter und Sachen je slikovno gradivo, s katerim v etimološkem 
- $\quad$ slovarju (in tudi v posameznih člankih) ponazarja obravnave nekaterih besed (npr. [स brah,jařmo, práh, kozlub, štětt, záboj). Slikovno gradivo je bilo namreč skorajda

2 Sebrané spisy Václava Machka v dveh knjigah na skupno 2296 straneh so izdelali priznani brnski etimologi Ilona Janyšková, Helena Karlíková in Radoslav Večerka, ki aktivno sodelujejo pri projektu Etymologický slovník jazyka staroslověnského, pri izdelavi Zbranih spisov pa je še sodelovala pokojna Eva Havlová (1929-2010), ki je bila tako kot tudi Radoslav Večerka še Machkova učenka. Pri izdelavi tega obsežnega dela sta torej sodelovali dve generaciji brnskih etimologov.

Kot ponazarja naslov, so v delu ponovno objavljeni vsi Machkovi objavljeni prispevki razen monografskih. Avtorji so jih tematsko razdelili v tri skupine: Razprave in članki (Studie a články, 21-1560), Recenzije, poročila, uredniške pripombe, ocene idr. (Recenze, zprávy, redakční poznámky, posudky aj., 1561-2038) in Nekrologi (Nekrology, 2039-2087). Vsi prispevki so bili stavljeni ponovno, paginacija iz izvirnikov pa je posebej označena. Znotraj vseh treh skupin so prispevki kronološko razvrščeni, pod naslovom vsakega pa je podan vir prve objave.

Pohvalno je, da so se avtorji odločili in tu prvič objavili njegova predavanja z naslovom Študij indoevropskega besednega zaklada (Studium indoevropské slovní zásoby, 2089-2130) iz študijskega leta 1961/62. Sledi bogat seznam naslovov njegovih predavanj in seminarjev od študijskega leta 1931/32 do 1964/65 pod naslovom Seznam přednášek a seminárù vedených Václavem Machkem na Filozofické fakultě v Brně (2131-2138). Pod naslovom Činnost Václava Machka v redakčních radách časopisů (2139) spoznamo čas Machkovega uredniškega delovanja v strokovnih revijah Naše řeč, Listy filologické in Sborník prací filosofické fakulty brněnské univerzity. Temu sledi Bibliografie Václava Machka (2140-2165), ki obsega 428 enot, vsaki enoti pa je dodan podatek, na katerih straneh ponovne objave se prispevek nahaja. Na koncu bibliografije lahko iz seznama okrajšav časopisov vidimo, da je Machek precej publiciral tudi v tujem strokovnem tisku, in sicer v revijah Bulletin de la Société de Linguistique de Paris (Pariz), Indogermanische Forschungen (Berlin), Zeitschrift für vergleichende Sprachforschung auf dem Gebiete der indogermanischen Sprachen (Berlin - Gütersloh - Göttingen; po letu 1988 revija izhaja pod novim naslovom Historische Sprachforschung), Revue des Études slaves (Pariz), Zeitschrift für Slavische Philologie (Leipzig - Wiesbaden - Heidelberg) in Zeitschrift für Slawistik(Berlin). Zanimiv je razdelek Práce o Václavu Machkovi (2166-2181), v katerem so za čas v letih 1930-2011 zbrane recenzije in drugi odmevi na Machkov jezikoslovni opus. Presenetljivo hitro so se domači in tuji avtorji odzvali že ob izidu njegove prve monografije Studie a tvoření výrazů expresivnich, med njimi tudi Antoine Meillet (1866-1936), ki je recenziral obe prvi Machkovi monografiji.

Delo zaključujejo kazala, in sicer kazalo navedenih osebnih imen (Rejstřik jmenný, 2182-2190), stvarno kazalo (Rejstř́k věcný, 2191-2201) in besedno kazalo (Rejstřík slovní, 2202-2296). Za slovenski prostor je zanimivo, da je Machek med raziskovalci citiral Rajka Nahtigala (1877-1958) in Karla Oštirja (1888-1973), mladi Bezlaj (1910-1993) pa v kazalu navedenih osebnih imen nastopa kot poročevalec Machkovih člankov Trois noms slaves de couleurs in Quelques noms slaves de 
plantes ter kot pisec nekrologa. Obsežno besedno kazalo prinaša vso leksiko iz vseh, tudi neindoevropskih jezikov, ki jih je Machek obravnaval v svojih spisih. Vanje so vključene tudi rekonstrukcije (pra)slovanskega in praindoevropskega leksikalnega fonda. Slovenščina je v kazalih zastopana z 248 različnimi leksemi.

Besedilu uvoda (Předmluva, 11-12) izpod peresa Ilone Janyškove, v katerem so Zbrani spisi Václava Machka kratko predstavljeni, sledi prikaz Machkovega življenja in dela (Václav Machek -život a dílo, 13-19), ki ga je prispevala Eva Havlová.

$3 \quad$ Korespondence I-II (1031 str.) je izšla kot 12. številka knjižne zbirke Studia etymologica Brunensia, izdelala in tudi uredila pa sta jo predstavnika najmlajše generacije brnskih etimologov Vít Boček in Petr Malčík. ${ }^{4}$

Urednika sta v izdelavo te publikacije vložila ogromno dela, saj je v publikaciji za obdobje med letoma 1929 in 1965 objavljenih 1620 pisem (največ jih je iz obdobja po drugi svetovni vojni) $\mathrm{z}$ več kot 400 različnimi naslovniki. Kot napoveduje naslov, je $\mathrm{v}$ delu objavljena korespondenca, tj. Machkova poslana in sprejeta pisma. To je bilo namreč mogoče realizirati, ker je imel Machek navado, da je svoja pisma tipkal v duplikatih. Večina korespondence je objavljena prvič. Manjši del je Eva Havlová že objavila v dveh člankih pod naslovom $Z$ korespondence Václava Machka $\mathrm{v}$ Listy filologické 127 (2004), 327-350, in Z vědecké korespondence mezi Brnem a Vídní v reviji Sborník prací Filozofické fakulty brněnské univerzity, Linguistica Brunensia 54, A 53 (2005), 198-202, Machkov dopis Jaroslavu B. Rudnyckemu pa je bil prvič objavljen v predgovoru An Etymological Dictionary of the Ukrainian Language, Winnipeg, 1962, X-XI.

Ker sta se urednika odločila za objavo vse korespondence, lahko v njej Machka spoznavamo kot jezikoslovca, ki si dopisuje s številnimi domačimi in tujimi jezikoslovci ali strokovnjaki drugih znanstvenih ved, ker ga kot etimologa zanimajo podrobnosti o realijah, kot urednika, avtorja, ki objavlja svoje članke, kot profesorja, prijatelja ... Ganljiv je prizor, ki ga podoživimo v najmlajšem izmed dopisov, v katerem leta 1965 dunajski indoevropeist Karl Treimer (1892-1976) Machka sprašuje, ali že ima krtačne odtise nove izdaje etimološkega slovarja, da bi o njem napisal obljubljeno recenzijo. Odgovor na to pismo ni več Machkov, ampak Eve Havlove, ki mu sporoča žalostno vest.

V korespondenci kot naslovniki nastopajo osebe, redakcije čeških in tujih časopisov, različne znanstvene in pedagoške ustanove, ministrstva, muzeji, založbe itd., ki v pismih ubesedujejo različno tematiko. Ker se tematika z različnih področij $\mathrm{v}$ enem pismu pogosto prepleta, sta se urednika odločila, da jo razvrstita po abecednem redu, znotraj tega pa seveda kronološko. Vsakega od naslovnikov sta pred dotično korespondenco tudi na kratko predstavila. Tako je npr. naš France Bezlaj, ki naj bi Machku pisal dvakrat, Machek pa njemu enkrat (vse v letu 1958), predstavljen z letnicama rojstva in smrti, opisno pa v slovenskem prevodu takole: »Slovenski

4 Prvi je v isti knjižni zbirki leta 2010 izdal monografijo Studie k nejstarším romanismům ve slovanských jazycích (Studia etymologica Brunensia 9), ki predstavlja prirejeno besedilo njegove disertacije, leta 2014 pa monografijo Praslovanština a jazykový kontakt (Studia etymologica Brunensia 17). 
- $\quad$ slavist. Študiral v Ljubljani in Pragi, deloval na univerzi v Ljubljani in na slovenski

[a akademiji znanosti. Ukvarjal se je zlasti s slovensko etimologijo in onomastiko,

N pa tudi s tujimi vplivi na slovenščino. Je avtor slovenskega etimološkega slovarja

- [Bezlaj 1976-2007]. Bil je urednik časopisa Slavistična revija«.

Osrednjemu delu s korespondenco, ki se razteza na skupno 943 straneh, sta urednika na začetku vsakega od obeh delov dodala kazalo. V prvem delu kazalu sledijo trije razdelki - Predgovor (Předmluva, 9-17), Uredniška pojasnila (Ediční poznámky, 19-22) in Zahvala (Poděkování; 23). Na koncu drugega dela so v razdelku Literatura (981-1017) zbrani bibliografski podatki o delih, ki so navedena v korespondenci (opozorilo, da je enota bibliografsko razložena, je v pismih navedeno med oglatima oklepajema), kazalo osebnih imen (Jmenný rejstřik, 1019-1031) pa nas seznanja z imeni oseb, ki v Korespondence I-II nastopajo kot avtorji pisem ali pa so $\mathrm{v}$ pismih omenjeni.

4 Gotovo ni naključje, da sta publikaciji Sebrané spisy Václava Machka 1-2 in Korespondence I-II ižsli sočasno, v istem letu. Časovno usklajeno dejanje treh generacij brnskih etimologov, Eve Havlove in Radoslava Večerke, Ilone Janyškove in Helene Karlíkove ter Víta Bočka in Petra Malčíka, je odraz skrbno načrtovanega in izvrstno izpeljanega skupnega dela. $Z$ njim se brnska etimološka delavnica ni le najbolje poklonila spominu svojega ustanovitelja, učitelja in vzornika, ampak je istočasno postavila zelo visok standard pri izdajanju tovrstnih del, ki so dandanes v vsaki stroki izjemno koristna, saj z ustvarjanjem boljših delovnih razmer zagotavljajo, da raziskovalni dosežki starejših generacij ne bi potonili v pozabo. Taki medgeneracijski mostovi so zato pomemben dejavnik pri neobhodnem ohranjanju kontinuitete znanstvene misli in diskurza v vsaki stroki, tudi primerjalnojezikoslovni in etimološki. 